\title{
Thermodynamic study of competitive inhibitors' binding to urease
}

\author{
Barbara Krajewska $^{1} \cdot$ Małgorzata Brindell $^{1}$
}

Received: 7 August 2015/Accepted: 31 October 2015/Published online: 29 December 2015

(c) The Author(s) 2015. This article is published with open access at Springerlink.com

\begin{abstract}
Three competitive inhibitors of urease: boric acid, 2-mercaptoethanol and phosphate buffer $\mathrm{pH} 6.45$, were subjected to the studies of temperature effects on their binding to the enzyme. The first of their kind for these systems, the studies were carried out at temperatures between 15 and $35^{\circ} \mathrm{C}$ in HEPES buffers. The Michaelis $K_{\mathrm{M}}$ and inhibition $K_{\mathrm{i}}$ constants determined for the uninhibited and inhibited urease reactions, respectively, were found to increase with an increase in temperature, importantly, the inhibition remaining competitive irrespective of temperature. The inverse of the constants were further analyzed as equilibrium constants of substrate and inhibitor binding reactions resulting in the formation of ES and EI complexes. The reactions were thermodynamically analyzed with use of the van't Hoff equation. Found $\mathrm{pH}-\mathrm{in}$ dependent in the $\mathrm{pH}$ range 6.45-7.0, the changes in the standard enthalpy $\left(\Delta H^{\circ}=-14 \mathrm{~kJ} \mathrm{~mol}^{-1}\right)$ and the Gibbs free energy $\left(\Delta G_{298}^{\circ}=-14 \mathrm{~kJ} \mathrm{~mol}^{-1}\right)$ for the substrate binding were negative, proving favorable for an exothermic and spontaneous reaction. With the standard entropy change $\Delta S^{\circ}$ close to zero, the reaction is enthalpy driven. The thermodynamic functions of the inhibitor binding by contrast, were found strongly correlated with the inhibitory strengths of the inhibitors in the order: boric acid $>$ 2-mercaptoethanol $>$ phosphate buffer $\mathrm{pH}$ 6.45. Accordingly, boric acid demonstrated the changes in the thermodynamic functions considerably bigger $\left(\Delta H^{\circ}=\right.$ $-42 \mathrm{~kJ} \mathrm{~mol}^{-1}, \Delta G_{298}^{\circ}=-23 \mathrm{~kJ} \mathrm{~mol}^{-1}$ ) than the substrate and the other two inhibitors. Those for 2-mercaptoethanol
\end{abstract}

Barbara Krajewska

krajewsk@chemia.uj.edu.pl

1 Faculty of Chemistry, Jagiellonian University, Ingardena 3, 30-060 Kraków, Poland were $\Delta H^{\circ}=-20 \mathrm{~kJ} \mathrm{~mol}^{-1}$ and $\Delta G_{298}^{\circ}=-17 \mathrm{~kJ} \mathrm{~mol}^{-1}$, while for phosphate buffer $\mathrm{pH} 6.45, \Delta H^{\circ}=-17 \mathrm{~kJ} \mathrm{~mol}^{-1}$, and $\Delta G_{298}^{\circ}=-13 \mathrm{~kJ} \mathrm{~mol}^{-1}$, and although slightly bigger, they were found practically comparable in value with those of the substrate, features that apparently result from the comparable values of $K_{\mathrm{M}}$ and $K_{\mathrm{i}} \mathrm{s}$. Remarkably, the inhibitors showed negative values of $\Delta S^{\circ}$ (to various degrees) proving that their binding to the enzyme, like that of the substrate, is driven by enthalpy.

Keywords Urease - Competitive inhibitors - Boric acid . 2-Mercaptoethanol · Phosphate buffer · Thermodynamics

\section{Introduction}

Urease (urea amidohydrolase, EC 3.5.1.5) is an enzyme whose catalytic function is to hydrolyze urea [1-3]. The products of the catalytic reaction are ammonia and carbamic acid, but on account of the spontaneous hydrolysis of the latter the observed products are ammonia and carbonic acid:

$\left(\mathrm{NH}_{2}\right)_{2} \mathrm{CO} \underset{\mathrm{H}_{2} \mathrm{O}}{\stackrel{\text { urease }}{\longrightarrow}} \mathrm{H}_{2} \mathrm{~N}-\mathrm{COOH}+\mathrm{NH}_{3} \underset{\mathrm{H}_{2} \mathrm{O}}{\stackrel{\text { spontaneous }}{\longrightarrow}} \mathrm{H}_{2} \mathrm{CO}_{3}+2 \mathrm{NH}_{3}$

In view of the wide distribution of urease and wide availability of urea in nature, the catalytic reaction [Eq. (1)] makes urease an enzyme that plays a prominent role in the global $\mathrm{N}$-cycle.

Urease is found in numerous plants, fungi, bacteria, algae, some invertebrates, and in soils as a soil enzyme [1-4]. Depending on the source, the structural organization of urease varies; typically, in plants and fungi urease is a 
hexamer of identical subunits (ca. $90 \mathrm{kDa}$ each), whereas in bacteria (except Helicobacter pylori urease) it consists typically of three different subunits that join together to form trimers. The bacterial trimer aligns with the single subunit of plant/fungal enzyme exhibiting 50-60\% homology of amino acid sequences. Most importantly, irrespective of the source and composition, the salient feature of ureases is a two-Ni(II) ions-containing active site [5] with a characteristic structure found conserved among the enzymes (Fig. 1a) [6-10]. This fact allows assuming that all ureases employ the same catalytic mechanism.

\section{Urease inhibition studies}

Further to theoretical knowledge on urease biochemistry, studies of urease inhibitions are carried out to assure compounds that could control enzyme activity in an effective, dependable and safe manner. The need for such control arises from different medical, environmental and engineering circumstances as discussed below.

Of great significance, the hydrolysis of urea [Eq. (1)] has two consequential features: it produces $\mathrm{NH}_{3}$ and alkalinizes its environment, both capable of causing deleterious complications, notably in medical and agricultural contexts [1, 3]. In the former, bacterial ureases may act as a virulence factor giving rise to pathological conditions [11-13], such as urinary stone formation and pyelonephritis resulting from the infection of the urinary tracts (chiefly with Proteus mirabilis and Ureaplasma urealyticum), and peptic ulcer disease, gastric cancer and hepatic coma resulting from the infection of the gastrointestinal tracts (primarily with Helicobacter pylori). Due to the growing resistance of the pathogens to antibiotics, the use of urease inhibitors has been considered as a therapeutic alternative. In the agricultural context by contrast, urease in soils plays a crucial role in the N-uptake by plants in the form of $\mathrm{NH}_{3}$ produced from the hydrolysis of fertilizer urea [14-16]. However, if too rapid, the hydrolysis may lead to overproduction of ammonia resulting in detrimental effects, such as losses of nitrogen by ammonia volatilization, and ammonia- and alkaline-induced plant damage. Given the fact that urea now makes up over $50 \%$ of the total $\mathrm{N}$-fertilizer worldwide, the problem may have serious environmental and economic consequences. One
Fig. 1 Schematic structures of the active site of urease: a native [7], and inhibited by b boric acid [40],

c 2-mercaptoethanol [29] and d phosphate [54]

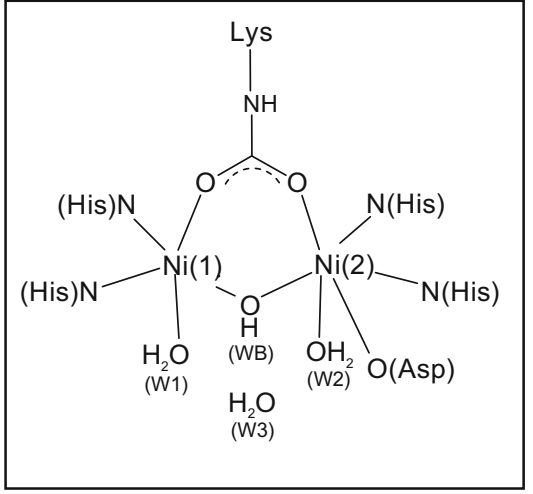

native urease

(a)

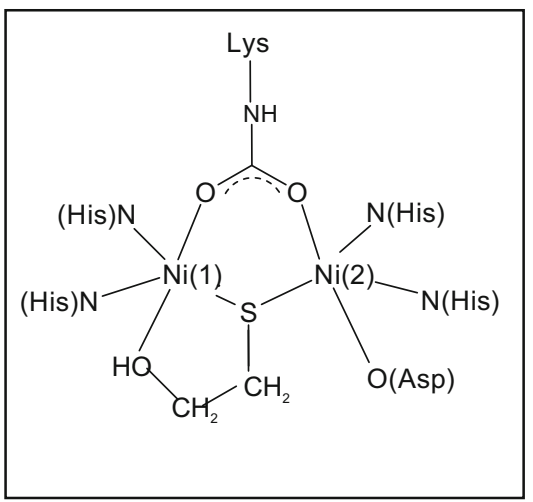

2-mercaptoethanol-inhibited urease

(c)

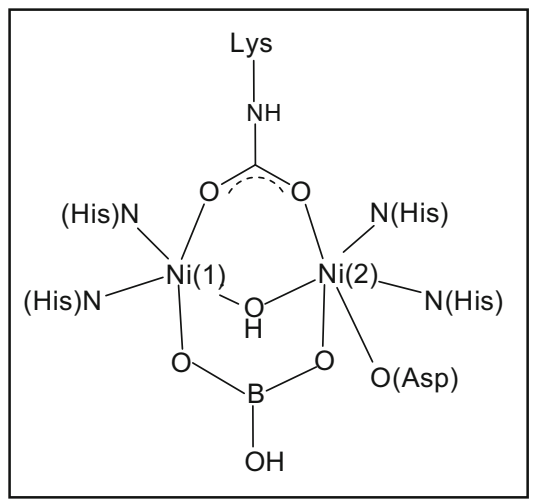

boric acid-inhibited urease

(b)

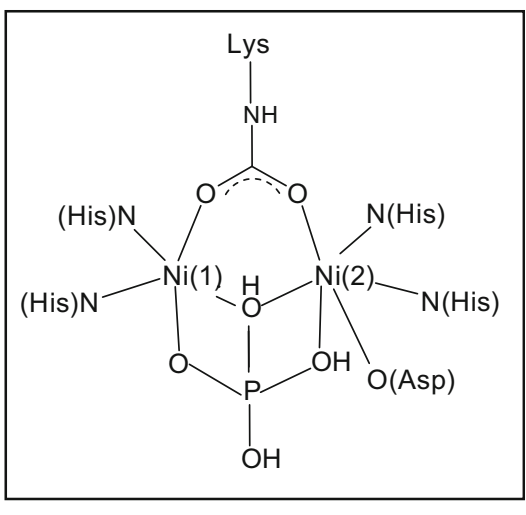

phosphate-inhibited urease

(d) 
way to counteract them is to suppress ureolytic activity of soils with use of urease inhibitors.

Another context, where urease activity participates, is calcium carbonate biomineralization. The process is achieved owing to an increase in $\mathrm{pH}$ and production of carbonate ions in the urea hydrolysis [Eq. (1)], which in the presence of $\mathrm{Ca}^{2+}$ ions are precipitated in the form of $\mathrm{CaCO}_{3}$ [17]. In addition to the significance in nature, this biocatalytic calcification offers potential in innovative engineering applications, such as preparation of advanced carbonate materials [17], cleaning waste- and groundwaters of $\mathrm{Ca}^{2+}$ and ${ }^{90} \mathrm{Sr}^{2+}$ [18], and most excitingly, sealing cracks and fissures in buildings [19] and other stone historic monuments of cultural heritage for their restoration [20].

Interestingly, urease inhibition can also be advantageously exploited as an analytical technique in ureasebased biosensors for the analysis of substances that act as inhibitors of the enzyme [21]. The measurements are based on the amount of inhibition provoked by the inhibitors, and they make use of enzyme sensitivity to sometimes infinitesimal concentrations of some inhibitors. As yet suffering from the lack of stability and selectivity, such biosensors offer enormous potential for measuring trace levels of compounds in environmental monitoring, food control and biomedical analysis.

Several classes of compounds are known to inhibit urease [1, 22-24]. These include amides and esters of phosphoric acid [7, 25-27], thiols [26-30], hydroxamic acids [26, 31-33], phosphinic and thiophosphinic acids [34-36], boric and boronic acids [37-43], heavy metal ions and their complexes [43-48], bismuth compounds [49], quinones [50-52], phosphate [26, 41, 53, 54], fluoride $[27,32,55,56]$ and to a lesser extent other compounds $[1,22-24,57,58]$. Despite the ongoing research in this area, the choice of inhibitors qualifying for effective and dependable application in controlling urease activity is still very limited.

Of the inhibitors listed above, three competitive inhibitors of different inhibitory strengths, representing different classes of compounds, were chosen for this study: boric acid, 2-mercaptoethanol and phosphate buffer $\mathrm{pH} 6.45$. Their inhibition constants reported in the literature are assembled in Table 1 and the schematic structures of their complexes with urease in Fig. 1. The following are the main features of the inhibitors.

Boric acid was shown to act as a urease inhibitor in the molecular form $\mathrm{B}(\mathrm{OH})_{3}[37,41,59]$. The crystal structure of the boric acid-urease complex (Fig. 1b) [40] revealed that $\mathrm{B}(\mathrm{OH})_{3}$ replaces $\mathrm{W} 1-\mathrm{W} 3$ water molecules in the active site, leaving in place the bridging water WB. The inhibitor binds to the $\mathrm{Ni}$ ions with its two $\mathrm{O}$-atoms, while the third one points toward the opening of the site. By contrast, 2-mercaptoethanol was shown to inhibit urease in its thiolate form $\mathrm{OH}-\mathrm{CH}_{2}-\mathrm{CH}_{2}-\mathrm{S}^{-}$[26]. The crystal structure of the inhibitor-enzyme complex (Fig. 1c) [29] demonstrated that 2-mercaptoethanol binds to urease active site by displacing all four water molecules. The inhibitor $\mathrm{S}$-atom bridges the $\mathrm{Ni}$ ions, while its $\mathrm{OH}$ group binds to Ni(1). Phosphate buffer, on the other hand, had its inhibitory strength shown $\mathrm{pH}$-dependent; the strength decreases with an increase in $\mathrm{pH}$ to cease at $\mathrm{pH} 7.0-7.5[26,53]$. The inhibitory action of the buffer was ascribed to $\mathrm{H}_{2} \mathrm{PO}_{4}^{-}$ion $[26,27,53]$, a point verified by the crystal structure of the urease-phosphate complex at $\mathrm{pH} 6.3$ [54]. In the structure (Fig. 1d), $\mathrm{H}_{2} \mathrm{PO}_{4}^{-}$ion replaces all four water molecules. One $\mathrm{OH}$ group of $\mathrm{H}_{2} \mathrm{PO}_{4}^{-}$bridges the $\mathrm{Ni}$ ions, while the other two $\mathrm{O}$-atoms bind to the $\mathrm{Ni}$ ions and the fourth one points toward the opening of the site.

\section{Competitive inhibition}

In competitive inhibition, an inhibitor $I$ binds to the free enzyme $E$ in a manner that prevents substrate $S$ binding [60]. The equilibria describing competitive inhibition are as follows:

$$
\begin{aligned}
& \quad \stackrel{K_{\mathrm{D}}}{\rightleftarrows} E S \stackrel{k_{2}}{\rightarrow} E+P \\
& \quad E+S \stackrel{ }{\rightleftarrows} E S \\
& \quad I \\
& K_{\mathrm{i}} \uparrow \downarrow \\
& \quad E I
\end{aligned}
$$

where $K_{\mathrm{D}}=E \cdot S / E S$ is the equilibrium constant for the $E S$ dissociation, $K_{\mathrm{i}}=E \cdot I / E I$ is the equilibrium constant for the $E I$ dissociation, and $k_{2}$ is the rate constant for the breakdown of $E S$ to $E+P$.

The Michaelis-Menten equation describing the uninhibited reaction is:

$v_{0}=\frac{v_{\max } S}{K_{\mathrm{M}}+S}$

where $K_{\mathrm{M}}$ is the Michaelis constant and $v_{\max }$ is the maximum reaction rate, in competitive inhibition changes into the following rate equation:

$v_{0}=\frac{v_{\max } S}{K_{\mathrm{M}}\left(1+\frac{I}{K_{\mathrm{i}}}\right)+S}$

where $K_{\mathrm{i}}$ is the inhibition constant and the expression $K_{\mathrm{M}}\left(1+I / K_{\mathrm{i}}\right)$ denotes the apparent Michaelis constant $K_{\mathrm{M}}^{\mathrm{app}}$. As shown, competitive inhibition increases $K_{\mathrm{M}}$, but does not affect $v_{\max }$.

To diagnose the type of inhibition, most commonly the Lineweaver-Burk double reciprocal plot of the rate 
Table 1 Inhibition constants of the studied inhibitors (ambient temperature), reported in the literature

\begin{tabular}{llll}
\hline Urease source & \multicolumn{1}{l}{$K_{\mathrm{i}} / \mathrm{mM}$} & & 2-Mercaptoethanol \\
\cline { 2 - 4 } & Boric acid & & Phosphate buffer $\mathrm{pH} 6.45$ \\
\hline Plant & & $0.72[27], 0.87[30]$ & $3.6[53]$ \\
Jack bean & $0.12[39], 0.08[41]$ & - & - \\
Pigeon pea & $0.35[42]$ & - & - \\
Soybean & $0.20[43]$ & & - \\
Bacterial & & - & $5[26]$ \\
Proteus mirabilis & $0.099[37]$ & $0.55[26]$ & - \\
Klebsiella aerogenes & $0.34[38]$ & $4.1[28]$ & \\
Helicobacter pylori & - &
\end{tabular}

equation is used, which for the competitive inhibition has the form:

$\frac{1}{v_{0}}=\frac{K_{\mathrm{M}}}{v_{\max }}\left(1+\frac{I}{K_{\mathrm{i}}}\right) \frac{1}{S}+\frac{1}{v_{\max }}$

In competitive inhibition, the reciprocal plots, $1 / v_{0}$ versus $1 / S$, intersect at $y$-axis. Further, the replot of the slope $=K_{\mathrm{M}}^{\mathrm{app}} / v_{\max }$ of the reciprocal plots [Eq. (5)] against inhibitor concentration $I$ provides the inhibition constant $K_{\mathrm{i}}=$-intercept on the $I$-axis.

Alternatively, for diagnosing the inhibition the Dixon plot may be used. The plot is a linear transformation of Eq. (4) where the inhibitor concentration $I$ is a variable:

$\frac{1}{v_{0}}=\frac{K_{\mathrm{M}}}{v_{\max } S K_{\mathrm{i}}} I+\frac{1}{v_{\max }}\left(1+\frac{K_{\mathrm{M}}}{S}\right)$

In competitive inhibition, the plots $1 / v_{0}$ versus $I$ recorded at unsaturating $S$ concentrations intersect above the $I$-axis at $I=-K_{\mathrm{i}}$.

As argued in the preceding paragraphs, there is a compelling need to investigate urease inhibition in order to ascertain new inhibitors and even more importantly, to better develop strategies for knowledge-based urease activity control. Several approaches can be applied in such investigations, i.e., crystallographic studies of enzyme-inhibitor complexes [7, 29, 33, 40, 54, 56], structure-based molecular designs [34-36, 61] in addition to indispensable kinetic studies. It is in the latter context that in this work we offer a thorough temperature-dependent kinetic investigation of the inhibition of urease by three competitive inhibitors representing different inhibitory classes: boric acid, 2-mercaptoethanol and phosphate buffer $\mathrm{pH}$ 6.45. This investigation is the first of its kind performed for these systems. Earlier, only prefatory results on the thermodynamics of urease inhibition by heavy metal ions were reported in this journal $[68,69]$. In this present work, the thermodynamics of the binding of the chosen inhibitors to the enzyme is comprehensively studied, interpreted in terms of their affinity to the enzyme and compared with the binding of the substrate. Further, the driving forces of the binding of the substrate and inhibitors are discussed.

\section{Materials and methods}

\section{Materials}

Urease (from jack beans, type III, with nominal activity $27.2 \mathrm{U} \mathrm{mg}^{-1}$ solid), urea (for Molecular Biology), HEPES buffer (SigmaUltra) and 2-mercaptoethanol (purity $\geq 99.0 \%$ ) were from Sigma-Aldrich. Boric acid and phosphoric acid were from POCh, Poland. $200 \mathrm{mM}$ stock solutions of HEPES and phosphate buffers were prepared by neutralizing HEPES and phosphoric acid with $\mathrm{NaOH}$. The HEPES stock solutions were further diluted to obtain the concentrations and $\mathrm{pHs}$ required for each individual inhibitor: $20 \mathrm{mM} \mathrm{pH} 7.0$ for boric acid, $20 \mathrm{mM} \mathrm{pH} 6.45$ for phosphate buffer $\mathrm{pH} 6.45$, and $5 \mathrm{mM}$ pH 6.84 for 2-mercaptoethanol. All the enzyme mixtures contained $1 \mathrm{mM}$ EDTA. Ultrapure water (resistivity $18.2 \mathrm{M} \Omega \mathrm{cm}$ ) obtained from a Simplicity 185 Millipore system was used throughout.

\section{Urease-inhibitors reactions in the absence of substrate}

Urease-inhibitor incubation mixtures were prepared in the respective HEPES buffers. The mixtures contained $1 \mathrm{mg} \mathrm{mL}{ }^{-1}$ urease and an inhibitor, either boric acid at concentrations from the range $15.625-250 \mathrm{mM}$, or phosphate buffer $\mathrm{pH} 6.45$ at concentrations from the range 1-3.75 M. The mixtures were incubated with occasional stirring. During the incubations, periodically $0.4 \mathrm{~mL}$ aliquots were transferred into the assay mixtures $(20 \mathrm{~mL})$ containing $50 \mathrm{mM}$ urea in $20 \mathrm{mM}$ phosphate buffer $\mathrm{pH}$ 7.2, for enzyme residual activity (RA) determinations, where at 5 min reaction, samples of the reaction mixtures were withdrawn and the ammonia released was converted into 
indophenol, which was quantified by measuring the absorbance at $630 \mathrm{~nm}$ [62]. RA was expressed as percent of the activity of uninhibited urease. The measurements were carried out at room temperature. Interfering with the indophenol method [63], 2-mercaptoethanol was not included in the measurements.

\section{Determination of urease initial reaction rates $v_{0}$ in the presence of substrate and inhibitors}

For the urease reactions in the presence of boric acid and phosphate buffer $\mathrm{pH} 6.45$, the initial reaction rates $v_{0}$ were determined by measuring the amount of ammonia released from the enzymatic reaction. The reactions were performed in mixtures $(20 \mathrm{~mL})$ containing $20 \mathrm{mM}$ HEPES buffer of the respective $\mathrm{pHs}$, urea and the inhibitor, the latter two at chosen concentrations. The reactions were initiated by the addition of $0.2 \mathrm{~mL}$ of urease solution $\left(2 \mathrm{mg} \mathrm{mL}^{-1}\right.$ freshly prepared in the respective buffers) and carried out for $5 \mathrm{~min}$, when the samples were taken out for ammonia determination by the indophenol method [62].

Due to the interference with the indophenol method [63], the $v_{0}$ values of the urease reactions in the presence of 2-mercaptoethanol were assayed by a spectrophotometric method with use of phenol red [64]. The assays were performed in a stopped-flow unit (SX20, Applied Photophysics Ltd, Leatherhead, UK). The reaction mixtures in the unit were formed by mixing urease solution $\left(0.04 \mathrm{mg} \mathrm{mL}^{-1}\right)$ with the solution containing urea and the inhibitor, each at a chosen concentration, and phenol red (final concentration $6.675 \times 10^{-3} \mathrm{mg} \mathrm{mL}^{-1}$ ) in $5 \mathrm{mM}$ HEPES buffer $\mathrm{pH} 6.84$. The reactions were monitored by the increase in the absorbance at $560 \mathrm{~nm}$ for $200 \mathrm{~s}$ [64].

The inhibitions were studied at five temperatures between 15 and $35^{\circ} \mathrm{C}$. At each temperature, the solutions to be mixed for the $v_{0}$ measurement were conditioned for ca. $20 \mathrm{~min}$, whereas those in the stopped-flow unit, for ca. $5 \mathrm{~min}$.

\section{Determination of the inhibition constants $K_{\mathrm{i}}$ of the studied inhibitors}

The inhibition constants $K_{\mathrm{i}}$ of boric acid and phosphate buffer $\mathrm{pH} 6.45$ were derived from the $v_{0}$ rates measured in the presence of five inhibitor concentrations in the range of $0-0.45 \mathrm{mM}$ for boric acid and $0-20 \mathrm{mM}$ for phosphate buffer $\mathrm{pH}$ 6.45, at each inhibitor concentration for seven urea concentrations $S$ from the range $2-50 \mathrm{mM}$ in the respective buffers. The saturation curves, $v_{0}$ versus $S$, were constructed for each inhibitor concentration [Eq. (4)], from which the apparent Michaelis constants $K_{\mathrm{M}}^{\mathrm{app}}$ and the maximum reaction rates $v_{\max }$ were obtained by nonlinear regression. The inhibition constants $K_{\mathrm{i}}$ were determined from the plots of the ratio of the apparent $K_{\mathrm{M}}^{\mathrm{app}}$ to $v_{\max }$ versus inhibitor concentration $I$.

The inhibition constants $K_{\mathrm{i}}$ of 2-mercaptoethanol by contrast were obtained from the Dixon plots, $1 / v_{0}$ versus $I$ [Eq. (6)]. For that, the $v_{0}$ rates were measured at two urea concentrations (15 and $25 \mathrm{mM}$ urea), at each of them for four inhibitor concentrations $I$ from the range $0.25-2.0 \mathrm{mM}$.

To establish the temperature dependence of the inhibition constants $K_{\mathrm{i}}$, each set of the measurements was repeated for each inhibitor at five temperatures $(15,20,25,30$ and $35^{\circ} \mathrm{C}$ ).

The experimental uncertainties of the final values of $K_{\mathrm{M}}$, $K_{\mathrm{i}}$ and the thermodynamic parameters were estimated from the regression analysis.

\section{Results and discussion}

\section{Urease-inhibitor reactions in the absence of substrate: determination of $\mathbf{I C}_{\mathbf{5 0}}$}

Prior to measuring the urease $v_{0}$ rates in the urease-ureainhibitor mixtures for $K_{\mathrm{i}}$ determinations, it was checked whether the inhibitors equilibrated rapidly with urease to form urease-inhibitor complexes in a manner that is not time dependent. For that, the kinetic curves of urease-inhibitor reactions, RA versus time, were recorded for a range of the inhibitors' concentrations (Fig. 2). The curves reveal that both boric acid and phosphate buffer equilibrate rapidly with urease within the time shorter than $30 \mathrm{~s}$. Simultaneously, the $\mathrm{IC}_{50}$ values, i.e., inhibitor concentrations bringing about a $50 \%$ inactivation of the enzyme, were estimated (insets to Fig. 2) at $46 \mathrm{mM}$ for boric acid (in agreement with $\mathrm{IC}_{50}=50 \mathrm{mM}$ reported in [65]) and at ca. $4.7 \mathrm{M}$ for phosphate buffer $\mathrm{pH} 6.45$.

\section{Urease reactions in the presence of substrate and inhibitors: determination of $K_{\mathrm{i}}$}

Having established that the inhibitors are rapidly binding to urease, the $v_{0}$ rates of the urease reactions were measured at the varied inhibitors' and urea concentrations at each temperature.

For boric acid and phosphate buffer $\mathrm{pH} 6.45$, the results were assembled in the form of saturation curves, $v_{0}$ versus $S$, as presented for three representative temperatures, $15^{\circ}$, $25^{\circ}$ and $35^{\circ}$ in Figs. $3 \mathrm{a}$ and $4 \mathrm{a}$. The figures reveal that the urease reactions, whether in the presence or absence of the inhibitors, followed Michaelis-Menten kinetics [Eq. (3), (4)] at each temperature, and also that, as typically observed for enzymatic reactions, increasing the temperature increased the reaction rates. The kinetic parameters, $K_{\mathrm{M}}^{\mathrm{app}}$ and $v_{\max }$, 
Fig. 2 Kinetic curves of the reaction between urease and the inhibitors: boric acid and phosphate buffer $\mathrm{pH} 6.45$ for different inhibitors' concentrations, residual activity (RA) versus incubation time. Insets plots of RA as a function of inhibitors' concentration in the incubation mixtures

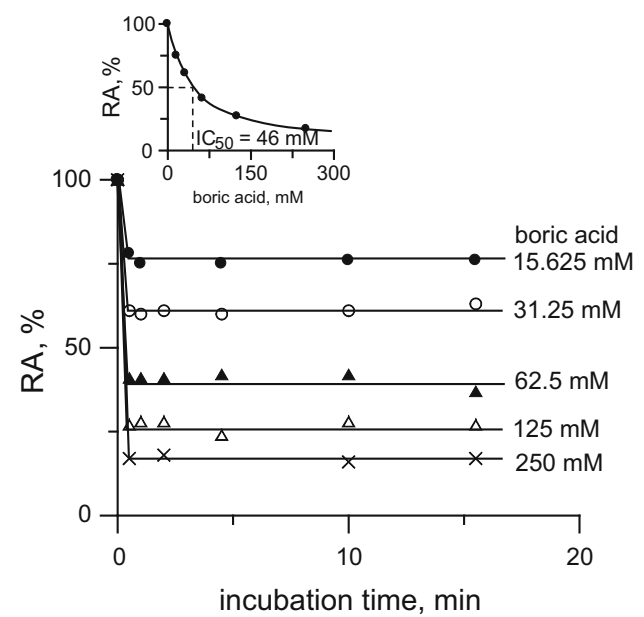

(a)

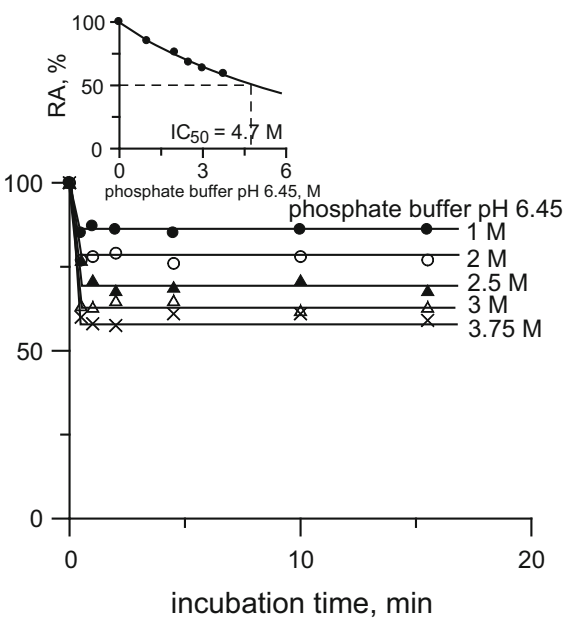

(b)
Fig. 3 Inhibition of urease by boric acid at 15,25 and $35^{\circ} \mathrm{C}$ : a saturation curves at different boric acid concentrations; b Lineweaver-Burk plots; c plots of the ratio of the apparent $K_{\mathrm{M}}^{\mathrm{app}} / v_{\max }$ versus boric acid concentration $15^{\circ} \mathrm{C}$

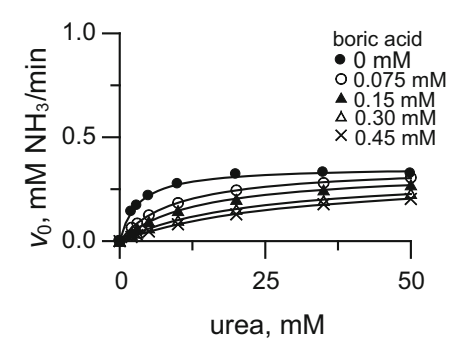

urea, $\mathrm{mM}$
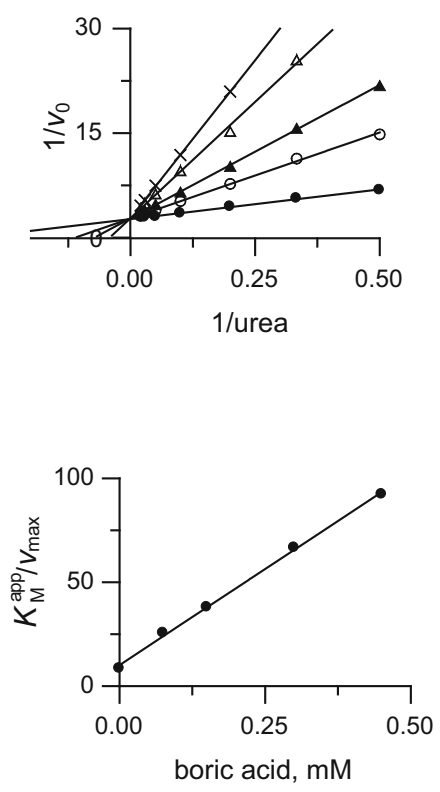

$25^{\circ} \mathrm{C}$

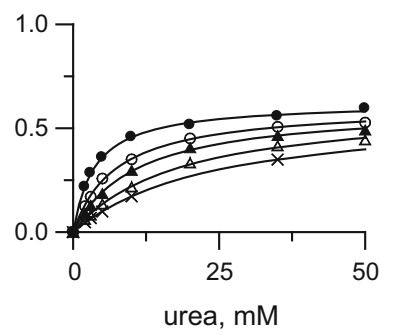

(a)
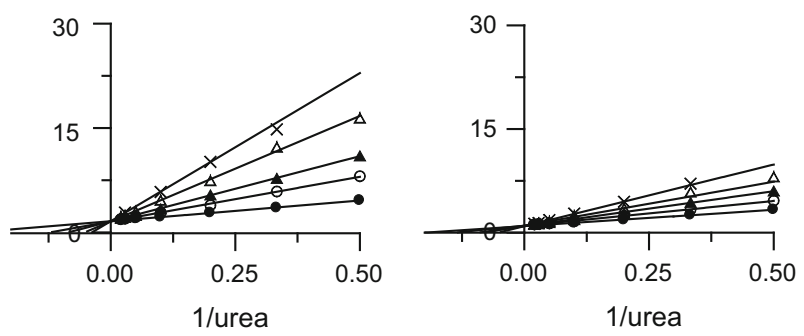

(b)
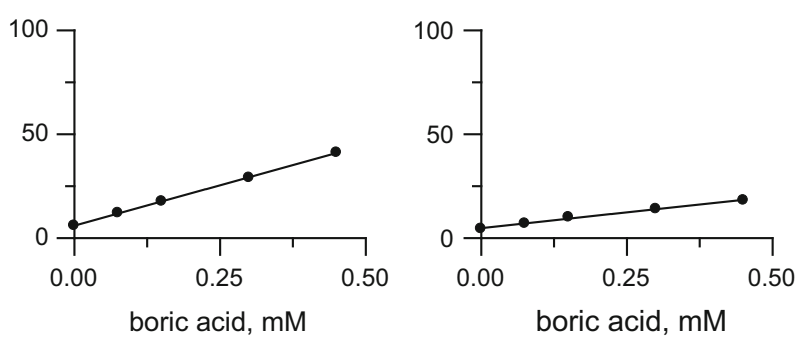

(c)

were derived from the curves, and the $K_{\mathrm{M}}$ values for the uninhibited reactions are listed in Table 2.

To ascertain whether temperature over $15-35^{\circ} \mathrm{C}$ affected the type of inhibition exerted by the studied inhibitors, the double reciprocal plots [Eq. (5)], $1 / v_{0}$ versus $1 / S$, were constructed. As shown in Fig. $3 b$ and $4 b$, in all the cases the linear plots intersect on the $y$-axis, proving that the inhibition is competitive irrespective of 
Fig. 4 Inhibition of urease by phosphate buffer $\mathrm{pH} 6.45$ at 15 , 25 and $35^{\circ} \mathrm{C}$ :

a saturation curves at different phosphate buffer concentrations;

b Lineweaver-Burk plots; c plots of the ratio of the apparent $K_{\mathrm{M}}^{\mathrm{app}} / v_{\max }$ versus phosphate buffer concentration $15^{\circ} \mathrm{C}$

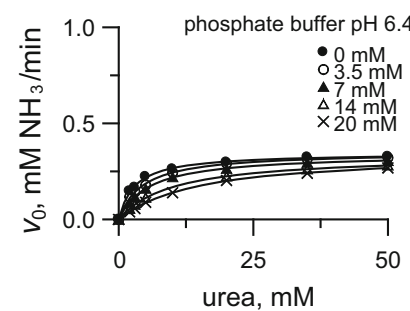

urea, $\mathrm{mM}$

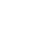

(a)
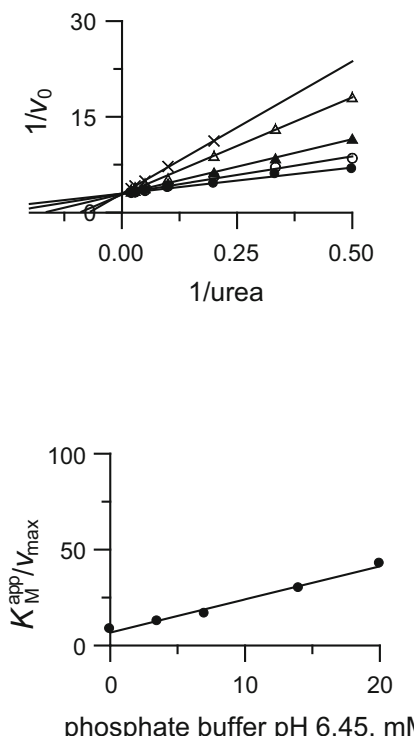

phosphate buffer $\mathrm{pH} 6.45, \mathrm{mM}$ $25^{\circ} \mathrm{C}$

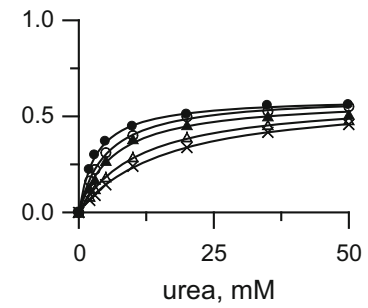

(a)
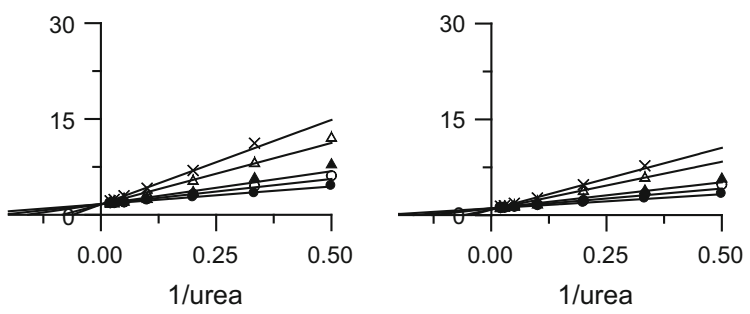

(b)
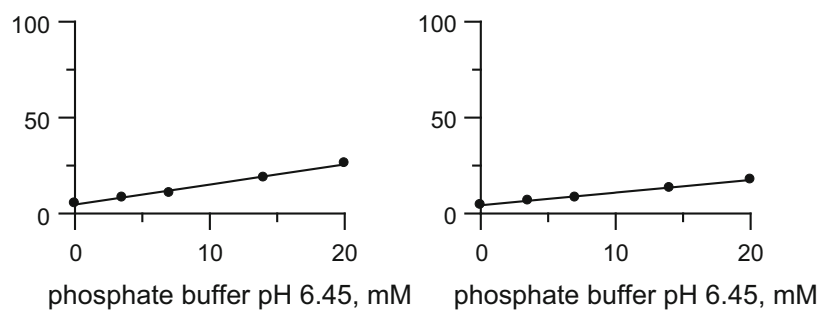

(c)
Table 2 Michaelis constants $K_{\mathrm{M}}$ of urease in the uninhibited reaction, measured at different temperatures and $\mathrm{pHs}$

\begin{tabular}{llll}
\hline$T /{ }^{\circ} \mathrm{C}$ & \multicolumn{3}{l}{$K_{\mathrm{M}} \times 10^{3} / \mathrm{M}$} \\
\cline { 2 - 4 } & $\mathrm{pH} 7.0$ & $\mathrm{pH} 6.84^{\mathrm{a}}$ & $\mathrm{pH} \mathrm{6.45}$ \\
\hline 15 & $3.1 \pm 0.2$ & $3.3 \pm 0.2$ & $2.7 \pm 0.2$ \\
20 & $3.5 \pm 0.1$ & $3.7 \pm 0.2$ & $3.0 \pm 0.1$ \\
25 & $3.7 \pm 0.2$ & $3.9 \pm 0.2$ & $3.2 \pm 0.1$ \\
30 & $4.2 \pm 0.2$ & $4.1 \pm 0.2$ & $3.6 \pm 0.1$ \\
35 & $4.5 \pm 0.3$ & $4.6 \pm 0.1$ & $4.0 \pm 0.2$ \\
\hline
\end{tabular}

${ }^{\mathrm{a}}$ Data taken from Ref. [64]

temperature in the range of $15-35^{\circ} \mathrm{C}$. Further, the plots of the ratio of the apparent $K_{\mathrm{M}}^{\mathrm{app}}$ to $v_{\max }$ (values taken from the saturation curves) versus $I$ were drawn (Fig. 3c, 4c), from which the inhibition constants $K_{\mathrm{i}}$ of boric acid and phosphate buffer $\mathrm{pH} 6.45$ were obtained. The $K_{\mathrm{i}}$ values are assembled in Table 3.

The results concerning 2-mercaptoethanol are presented in Fig. 5 in the form of the Dixon plots, $1 / v_{0}$ versus 2-mercaptoethanol concentration. The plots form straight lines that intersect at each temperature above negative section of $x$-axis, proving that the inhibition is competitive. The $K_{\mathrm{i}}$ values were read out as the negative values of the concentration of 2-mercaptoethanol corresponding to the intersection point. The values are listed in Table 3.

\section{Thermodynamic characterization of the uninhibited and inhibited urease reactions}

Typically in the Michaelis-Menten mechanism [Eq. (2)], the binding step in enzyme reactions consists of the formation of the enzyme-substrate complex ES in a reaction: $E+S \rightleftarrows E S$. The reaction is governed by the equilibrium constant equal to $1 / K_{\mathrm{D}}$, where $K_{\mathrm{D}}$ is the equilibrium constant for the $E S$ dissociation: $E S \rightleftarrows E+S$ [60].

By contrast, in competitive inhibition of enzymes [Eq. (2)], parallel to the substrate binding there occurs the inhibitor binding to the enzyme with the formation of the enzyme-inhibitor complex $E I$ in a reaction: $E+I \rightleftarrows E I$. The equilibrium of the reaction is expressed by the 
Table 3 Inhibition constants $K_{\mathrm{i}}$ of boric acid, 2-mercaptoethanol and phosphate buffer $\mathrm{pH}$ 6.45, measured at different temperatures

\begin{tabular}{llcc}
\hline$T /{ }^{\circ} \mathrm{C}$ & $K_{\mathrm{i}} \times 10^{3} / \mathrm{M}$ & \\
\cline { 2 - 4 } & Boric acid & 2-Mercaptoethanol & $3.9 \pm 0.5$ \\
15 & $0.055 \pm 0.005$ & $0.75 \pm 0.1$ & $4.2 \pm 0.4$ \\
20 & $0.057 \pm 0.001$ & $1.0 \pm 0.1$ & $4.4 \pm 0.3$ \\
25 & $0.077 \pm 0.001$ & $1.1 \pm 0.2$ & $4.8 \pm 0.5$ \\
30 & $0.121 \pm 0.003$ & $1.2 \pm 0.2$ & $6.5 \pm 0.2$ \\
\hline
\end{tabular}

Fig. 5 Inhibition of urease by 2-mercaptoethanol at 15, 25 and $35{ }^{\circ} \mathrm{C}$ : Dixon plots obtained for two non-saturating urea concentrations

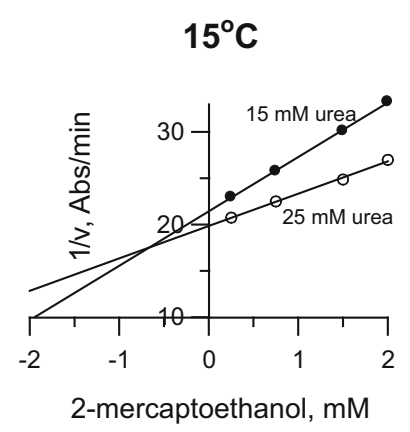

$15^{\circ} \mathrm{C}$

$25^{\circ} \mathrm{C}$

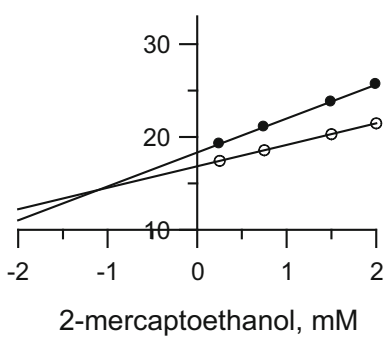

$35^{\circ} \mathrm{C}$

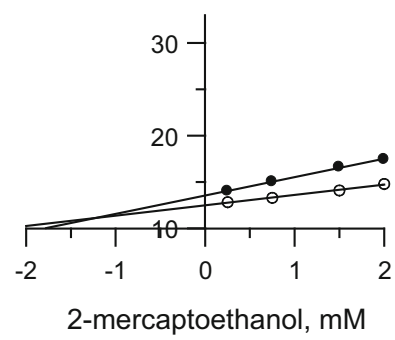

equilibrium constant equal to $1 / K_{\mathrm{i}}$, where $K_{\mathrm{i}}$ is the equilibrium constant for the $E I$ dissociation: $E I \rightleftarrows E+I$ [60].

Measuring the constants $K_{\mathrm{D}}$ and $K_{\mathrm{i}}$ at different temperatures enables the determination of the thermodynamic parameters for both the substrate and inhibitor binding to the enzyme, $\Delta H^{\circ}, \Delta S^{\circ}$ and $\Delta G^{\circ}$ (the standard enthalpy, entropy and the Gibbs free energy change of the reaction). The standard enthalpy $\Delta H^{\circ}$ and the entropy $\Delta S^{\circ}$ change can be assessed from the van't Hoff plot:

$-\ln K_{\text {eq }}=\frac{\Delta H^{\circ}}{R T}-\frac{\Delta S^{\circ}}{R}$

where $K_{\text {eq }}$ is the equilibrium constant of a chemical reaction, $T$ is the absolute temperature, and $R$ stands for the gas constant. From this plot, $\Delta H^{\circ} / R$ is the slope and $-\Delta S^{\circ} / R$ is the intercept of the linear fit. By contrast, the Gibbs free energy change $\Delta G^{\circ}$ for a given temperature can be obtained from the definition:

$\Delta G^{\circ}=\Delta H^{\circ}-T \Delta S^{\circ}$

\section{Effect of temperature on $K_{M}$}

To be able to analyze the thermodynamic parameters of the inhibitor binding relative to the substrate binding, first the uninhibited reaction will be thermodynamically characterized.

Listed in Table 2, the values of $K_{\mathrm{M}}$ determined in HEPES buffer at $\mathrm{pH} 7.0,6.84$ and 6.45, at temperatures between 15 and $35{ }^{\circ} \mathrm{C}$, agree with those reported in the literature [1]. A close inspection of the values reveals effects worthy of attention. One is that the $K_{\mathrm{M}}$ constants obtained at $\mathrm{pH} 7.0$ and 6.84 [64] are practically identical, whereas those obtained at $\mathrm{pH} 6.45$ are lower. This observation is in agreement with the effect of $\mathrm{pH}$ on $K_{\mathrm{M}}$ of urease reported in our previous works [41, 53]. Therein we showed that the dependence of $\mathrm{p} K_{\mathrm{M}}$ on $\mathrm{pH}$ takes up a form of a complex wave, where going from neutral toward lower pHs, $K_{\mathrm{M}}$ decreases to assume the lowest values at $\mathrm{pH}$ around 6. Although this decrease is rather small, it indicates that at this $\mathrm{pH}$ urease has the highest affinity for the substrate, which must be a result of favorable ionization states of the residues of the active site involved in the substrate binding.

Another effect revealed by the data in Table 2 is that contrary to the previously reported independence of temperature [66], the $K_{\mathrm{M}}$ values showed a slight increase by about $1.3 \mathrm{mM}$ between 15 and $35^{\circ} \mathrm{C}$ at each $\mathrm{pH}$ studied (ca. 1.4-fold increase). This indicates a small reduction in the enzyme affinity for the substrate at higher temperatures, which apparently can be regarded as resulting from the distortion of the active site structure.

Further, the thermodynamic parameters for the substrate-urease binding were examined. Importantly, in this examination, we followed the suggestion in the literature [67], based on insignificant variability of $K_{\mathrm{M}}$ with $\mathrm{pH}$ [41, 53, 66], that urease features $K_{\mathrm{M}}=K_{\mathrm{D}}$. Correspondingly, the plots of the inverse of the urease Michaelis constant $K_{\mathrm{M}}$ were constructed according to Eq. (7), $\ln K_{\mathrm{M}}$ versus $1 / T$, for the pHs studied (Fig. 6a), and the resulting parameters $\Delta H^{\circ}, \Delta S^{\circ}$ and $\Delta G_{298}^{\circ}$ [Eq. (8)] were compiled in 
Fig. 6 Effect of temperature in the range $15-35{ }^{\circ} \mathrm{C}$ on a the Michaelis constant $K_{\mathrm{M}}$ at pH 7.0 and 6.45,

b the inhibition constants $K_{\mathrm{i}}$ of boric acid, 2-mercaptoethanol and phosphate buffer $\mathrm{pH} 6.45$

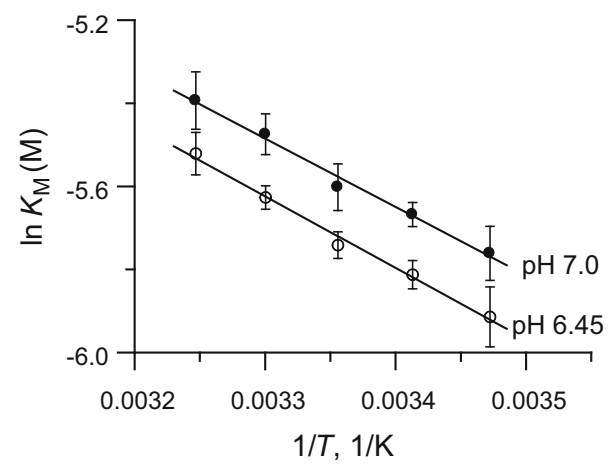

(a)

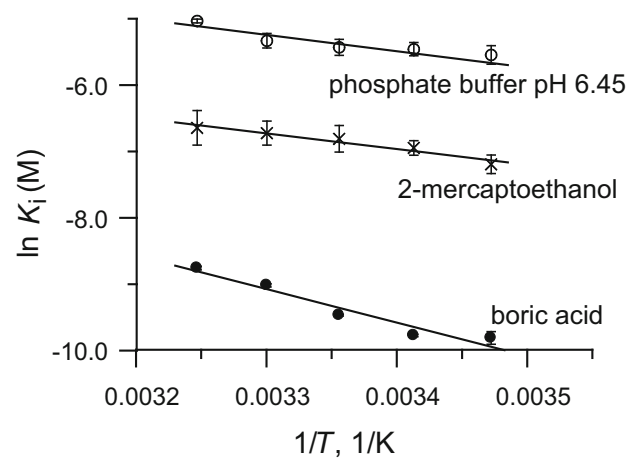

(b)
Table 4 Thermodynamic parameters for the formation of the ureaseurea complex ES in the uninhibited urease reaction, obtained from temperature-dependent measurements of $K_{\mathrm{M}}$ at different $\mathrm{pHs}$

\begin{tabular}{llrl}
\hline $\mathrm{pH}$ & $\Delta H^{\circ} / \mathrm{kJ} \mathrm{mol}^{-1}$ & $\Delta S^{\circ} / \mathrm{J} \mathrm{K}^{-1} \mathrm{~mol}^{-1}$ & $\Delta G_{298}^{\circ} / \mathrm{kJ} \mathrm{mol}^{-1}$ \\
\hline 7.0 & $-14 \pm 1$ & $0.4 \pm 3$ & $-14 \pm 1$ \\
$6.84^{\mathrm{a}}$ & $-12 \pm 1$ & $7 \pm 3$ & $-14 \pm 1$ \\
6.45 & $-14 \pm 1$ & $-0.5 \pm 3$ & $-14 \pm 1$ \\
\hline
\end{tabular}

${ }^{a}$ Data taken from Ref. [64]

Table 4. As shown, the thermodynamic parameters for the formation of the urease-urea complex are, within the limits of the experimental error, $\mathrm{pH}$-independent in the studied $\mathrm{pH}$ range. The standard enthalpy $\Delta H^{\circ}$ and the Gibbs free energy $\Delta G_{298}^{\circ}$ changes are negative, proving favorable for an exothermic and spontaneous reaction. The standard entropy change $\Delta S^{\circ}$, on the other hand, was found to be close to zero. This indicates that the extent of disorder of the reactants before and after the reaction of substrate binding is comparable; however, the interpretation of this entropy change may be difficult, as the change may be a composite of many different contributions that partially cancel each other. Importantly, the values of $\Delta H^{\circ}$ and $\Delta S^{\circ}$ indicate that the substrate binding in the urease reaction is driven by enthalpy.

\section{Effect of temperature on $K_{i}$}

The inhibition constants $K_{\mathrm{i}}$ of the studied inhibitors measured between 15 and $35^{\circ} \mathrm{C}$ (Table 3 ) are consistent in magnitude with those presented in the literature for the ambient temperature (Table 1), thus confirming that the inhibitory strength of the inhibitors follows the order: boric acid $>2$-mercaptoethanol $>$ phosphate buffer $\mathrm{pH} 6.45$.

The data in Table 3 reveal that for each studied inhibitor the inhibition constant $K_{\mathrm{i}}$ grew with temperature in the range of $15-35{ }^{\circ} \mathrm{C}$, nearly three times for boric acid, and less than two times for 2-mercaptoethanol and phosphate buffer $\mathrm{pH}$ 6.45. This growth of $K_{\mathrm{i}}$ implies that temperature diminishes the affinity of the inhibitors to urease, an effect being more pronounced for boric acid than for 2-mercaptoethanol and phosphate buffer $\mathrm{pH} 6.45$. To try to weigh whether these are temperature-provoked changes in the urease active site or in the inhibitors molecules that are responsible for the reduction of inhibitor-enzyme affinity, the Michaelis $K_{\mathrm{M}}$ and inhibition $K_{\mathrm{i}}$ constants were compared. As shown in Tables 2 and 3, while the $K_{\mathrm{M}}$ value of urease increased ca. 1.4-fold between 15 and $35{ }^{\circ} \mathrm{C}$ independent of the $\mathrm{pH}$ studied, the $K_{\mathrm{i}}$ value of boric acid increased ca. 2.8 times in the same temperature range. This comparison effectively implies that for the decrease in the affinity of boric acid to urease responsible are the changes in the boric acid molecules rather than in the urease active site. By the same token, the fact that $K_{\mathrm{i}}$ of 2-mercaptoethanol and phosphate buffer $\mathrm{pH} 6.45$ grew ca. 1.7 times between 15 and $35^{\circ} \mathrm{C}$ means that the responsibility for the reduction of the affinity of these inhibitors to urease lies with both the active site and the inhibitors.

In order to carry out a thermodynamic analysis of the inhibition of urease by the three inhibitors studied, the equilibrium constants of the binding reactions [Eq. (2)] equal to the inverse of $K_{\mathrm{i}}$ were plotted in the form of the van't Hoff plots, ln $K_{\mathrm{i}}$ versus $1 / T$ [Eq. (7)]. The plots are presented in Fig. $6 \mathrm{~b}$ and the resulting changes in the thermodynamic functions, in Table 5. Clearly, the location of the plots in Fig. $6 \mathrm{~b}$ and the values of the thermodynamic functions are directly consequent on the inhibitory strength of the inhibitors; the stronger is the inhibitor (the lower is its $K_{\mathrm{i}}$ value), the lower position its van't Hoff plot occupies. In the studied group of inhibitors, boric acid is the strongest inhibitor showing its $K_{\mathrm{i}}$ values that are, depending on temperature, two to one order of magnitude smaller than the $K_{\mathrm{M}}$ values of urease, while the $K_{\mathrm{i}}$ values of the other two inhibitors are comparable with $K_{\mathrm{M}}$. Consequently, boric acid demonstrated the changes in the thermodynamic functions in the binding reaction with urease considerably bigger than those of the substrate (Table 4) and those of the other two inhibitors (Table 5), a feature that clearly makes it distinct among the studied inhibitors. 
Table 5 Thermodynamic parameters for the formation of the urease-inhibitor complexes EI in the inhibited urease reaction, obtained from temperature-dependent measurements of $K_{\mathrm{i}}$

\begin{tabular}{llcr}
\hline Inhibitor & $\Delta H^{\circ} / \mathrm{kJ} \mathrm{mol}^{-1}$ & $\Delta S^{\circ} / \mathrm{J} \mathrm{K}^{-1} \mathrm{~mol}^{-1}$ & $\Delta G_{298}^{\circ} / \mathrm{kJ} \mathrm{mol}^{-1}$ \\
\hline Boric acid & $-42 \pm 6$ & $-63 \pm 21$ & $-23 \pm 6$ \\
2-Mercaptoethanol & $-20 \pm 3$ & $-9 \pm 9$ & $-17 \pm 3$ \\
Phosphate buffer pH 6.45 & $-17 \pm 4$ & $-12 \pm 14$ & $-13 \pm 4$ \\
\hline
\end{tabular}

The change in the enthalpy of the reaction $\Delta H^{\circ}=-42 \mathrm{~kJ} \mathrm{~mol}^{-1}$ proves that the reaction of boric acid with urease is markedly exothermic, more exothermic than the reaction of urease with the substrate $\left(-14 \mathrm{~kJ} \mathrm{~mol}^{-1}\right)$. Also, $\Delta G_{298}^{\circ}$ value of this reaction $\left(-23 \mathrm{~kJ} \mathrm{~mol}^{-1}\right)$ shows a similar feature, which proves that the reaction is more spontaneous than the other binding reactions under examination. Interestingly, compared to the reaction of substrate binding, boric acid binding shows a large negative value of $\Delta S^{\circ}=-63 \mathrm{~J} \mathrm{~K}^{-1} \mathrm{~mol}^{-1}$, clearly indicating that the system after the reaction is more orderly than before the reaction.

By contrast, correlated with their inhibitory strengths, the other two inhibitors studied, 2-mercaptoethanol and phosphate buffer $\mathrm{pH}$ 6.45, showed the changes in the thermodynamic functions in their reactions with urease smaller than boric acid; the reactions are less exothermic $\left(\Delta H^{\circ}=-20\right.$ and $-17 \mathrm{~kJ} \mathrm{~mol}^{-1}$, respectively) and less spontaneous $\left(\Delta G_{298}^{\circ}=-17\right.$ and $-13 \mathrm{~kJ} \mathrm{~mol}^{-1}$, respectively). Importantly, although these changes are slightly bigger than those for the substrate binding (Table 4), they are practically comparable in value, features that apparently result from the comparable values of $K_{\mathrm{M}}$ and $K_{\mathrm{i}} \mathrm{s}$. The binding of the two inhibitors to the enzyme is also similar to the substrate binding in respect of entropy change $\Delta S^{\circ}$. The estimated values of $\Delta S^{\circ}$ were found negative but quite small, and given the high experimental uncertainties, they can be viewed as close to zero.

Cumulatively, with respect to the driving force underlying the inhibitors' binding, on the basis of the above data it is possible to conclude that like that of the substrate, the binding reactions of all the three inhibitors studied are driven by enthalpy.

In this connection, it would be interesting to compare the data collected in this work with other thermodynamic urease inhibition data. However, as mentioned earlier the reports on the thermodynamics of urease inhibition are scarce in the literature. The available data are those on heavy metal ions inhibition, $\mathrm{Hg}^{2+}, \mathrm{Ag}^{+}, \mathrm{Cu}^{2+}, \mathrm{Zn}^{2+}$ and $\mathrm{Cd}^{2+}$ ions, measured with use of isothermal titration calorimetry [68-70]. Importantly, unlike the competitive inhibitors in this work, heavy metal ions are comparatively strong inhibitors of urease, strongest being $\mathrm{Hg}^{2+}, \mathrm{Ag}^{+}$and
$\mathrm{Cu}^{2+}$ [44-46], that act on urease in a slow-binding mode [45]. The inhibitory action of the ions was proven to be primarily through the reaction with the enzyme thiol groups [46]. Intriguingly, the reported thermodynamic parameters for the binding of the ions to urease [68-70] do not vary among the ions, maintaining practically the same values irrespective of the ions' inhibitory strength. The reported values are: $\Delta H^{\circ} \approx-14 \mathrm{~kJ} \mathrm{~mol}^{-1}$ (between -16 and $-13 \mathrm{~kJ} \mathrm{~mol}^{-1}$ ), $\Delta S^{\circ} \approx 19 \mathrm{~J} \mathrm{~K}^{-1} \mathrm{~mol}^{-1}$ (between 17 and $20 \mathrm{~J} \mathrm{~K}^{-1} \mathrm{~mol}^{-1}$ ), $\Delta G_{300}^{\circ} \approx-20 \mathrm{~kJ} \mathrm{~mol}^{-1}$ (between -21 and $-20 \mathrm{~kJ} \mathrm{~mol}^{-1}$ ). Thus, like in our inhibitions, these bindings are exothermic and spontaneous, but the most striking difference is that the entropy of the reaction system increased upon metal ions binding, whereas it decreased upon binding of the inhibitors studied in the present work. Consequently, unlike our inhibitions, which are solely enthalpy driven, the inhibition by the heavy metal ions is driven by both enthalpy and entropy. Obviously needing further studies to account for, these distinct differences in the thermodynamic behavior of the two groups of the inhibitors might at least in part now be explained by different mechanisms of the reaction with urease, different inhibitory strengths of the inhibitors and inevitably, by different experimental techniques applied.

\section{Conclusions}

Temperature-dependent study of the inhibition of urease by three competitive inhibitors: boric acid, 2-mercaptoethanol and phosphate buffer $\mathrm{pH}$ 6.45, was performed in HEPES buffer in the temperature range $15-35^{\circ} \mathrm{C}$. The Michaelis $K_{\mathrm{M}}$ and inhibition $K_{\mathrm{i}}$ constants determined for the uninhibited and inhibited urease reactions, respectively, were found to increase with an increase in temperature with the inhibition remaining competitive irrespective of temperature. To thermodynamically characterize the reactions of substrate and inhibitor binding to the enzyme resulting in the formation of the enzyme-substrate ES and enzymeinhibitor EI complexes, the inverse of the $K_{\mathrm{M}}$ and $K_{\mathrm{i}}$ constants were analyzed with use of the van't Hoff equation. For the substrate binding, the changes in the standard enthalpy $\left(\Delta H^{\circ}=-14 \mathrm{~kJ} \mathrm{~mol}^{-1}\right)$ and the free energy 
$\left(\Delta G_{298}^{\circ}=-14 \mathrm{~kJ} \mathrm{~mol}^{-1}\right)$ were found independent of $\mathrm{pH}$ in the range 6.45-7.0 and negative in value, proving favorable for an exothermic and spontaneous reaction. With the standard entropy change $\Delta S^{\circ}$ close to zero, the reaction is enthalpy driven. The thermodynamic functions of the inhibitors' binding reactions were found correlated with the inhibitory strengths of the inhibitors in the order: boric acid $>2$-mercaptoethanol $>$ phosphate buffer $\mathrm{pH}$ 6.45. Accordingly, the thermodynamic functions for boric acid binding were considerably bigger $\left(\Delta H^{\circ}=-42 \mathrm{~kJ} \mathrm{~mol}^{-1}, \quad \Delta G_{298}^{\circ}=-23 \mathrm{~kJ} \mathrm{~mol}^{-1}\right)$ than those of the substrate and the other two inhibitors, with $\Delta S^{\circ}$ assuming a large negative value of $-63 \mathrm{~J} \mathrm{~K}^{-1} \mathrm{~mol}^{-1}$. 2-Mercaptoethanol and phosphate buffer $\mathrm{pH}$ 6.45, by contrast, showed the changes in the thermodynamic functions smaller than those of boric acid $\left(\Delta H^{\circ}=-20\right.$ and $-17 \mathrm{~kJ} \mathrm{~mol}^{-1}$, and $\Delta G_{298}^{\circ}=-17$ and $-13 \mathrm{~kJ} \mathrm{~mol}^{-1}$, respectively). Although slightly bigger, they were found practically comparable in value with those of the substrate, including the change in $\Delta S^{\circ}$ found close to zero, features that apparently result from the comparable values of $K_{\mathrm{M}}$ and $K_{\mathrm{i}}$ s. Importantly, all the three inhibitors showed negative values of $\Delta S^{\circ}$ (to various degrees), proving that their binding to the enzyme, like that of the substrate, is driven by enthalpy.

Acknowledgements This work was supported by DS WCh/43 from Faculty of Chemistry of the Jagiellonian University, Kraków, Poland. The stopped-flow measurements were carried out with the equipment financed by the European Regional Development Fund within the framework of the Polish Innovation Economy Operational Program (Contract No. POIG.0 2.01.00-12-0 23/08).

Open Access This article is distributed under the terms of the Creative Commons Attribution 4.0 International License (http://creative commons.org/licenses/by/4.0/), which permits unrestricted use, distribution, and reproduction in any medium, provided you give appropriate credit to the original author(s) and the source, provide a link to the Creative Commons license, and indicate if changes were made.

\section{References}

1. Krajewska B. Ureases. I. Functional, kinetic and catalytic properties: a review. J Mol Catal B Enzym. 2009;59:9-21.

2. Maroney MJ, Ciurli S. Nonredox nickel enzymes. Chem Rev. 2014;114:4206-28.

3. Follmer C. Insights into the role and structure of plant ureases. Phytochemistry. 2008;69:18-28.

4. Polacco JC, Mazzafera P, Tezotto T. Opinion-Nickel and urease in plants: still many knowledge gaps. Plant Sci. 2013;199-200: 79-90.

5. Dixon NE, Gazzola C, Blakeley RL, Zerner B. Jack bean urease (EC 3.5.1.5). A metalloenzyme. A simple biological role for nickel. J Am Chem Soc. 1975;97:4131-3.

6. Jabri E, Carr MB, Hausinger RP, Karplus PA. The crystal structure of urease from Klebsiella aerogenes. Science. 1995;268: 998-1004.
7. Benini C, Rypniewski WR, Wilson KS, Miletti S, Ciurli S, Mangani S. A new proposal for urease mechanism based on the crystal structures of the native and inhibited enzyme from Bacillus pasteurii: why urea hydrolysis costs two nickels. Structure. 1999;7:205-16.

8. Ha N-C, Oh S-T, Sung JY, Cha KA, Lee MH, Oh B-H. Supramolecular assembly and acid resistance of Helicobacter pylori urease. Nat Struct Biol. 2001;8:505-9.

9. Balasubramanian A, Ponnuraj K. Crystal structure of the first plant urease from jack bean: 83 years of journey from its first crystal to molecular structure. J Mol Biol. 2010;400:274-83.

10. Balasubramanian A, Durairajpandian V, Elumalai S, Mathivanan N, Munirajan AK, Ponnuraj K. Structural and functional studies on urease from pigeon pea (Cajanus cajan). Int J Biol Macromol. 2013;58:301-9.

11. Follmer C. Ureases as a target for the treatment of gastric and urinary infections. J Clin Pathol. 2010;63:424-30.

12. Rutherford JC. The emerging role of urease as a general microbial virulence factor. PLoS Pathog. 2014;10:e1004062.

13. Burne RA, Chen Y-YM. Bacterial ureases in infectious diseases. Microb Infect. 2000;2:533-42.

14. Hasan HAH. Ureolytic organisms and soil fertility: a review. Commun Soil Sci Plant Anal. 2000;31:2565-89.

15. Mulvaney RL, Bremner JM. Control of urea transformation in soils. Soil Biochem. 1981;5:153-96.

16. Soares JR, Cantarella H, Menegale MLD. Ammonia volatilization losses from surface-applied urea with urease and nitrification inhibitors. Soil Biol Biochem. 2012;52:82-9.

17. Sondi I, Salopek-Sondi B. Influence of the primary structure of enzymes on the formation of $\mathrm{CaCO}_{3}$ polymorphs: a comparison of plant (Canavalia ensiformis) and bacterial (Bacillus pasteurii) ureases. Langmuir. 2005;21:8876-82.

18. Hammes F, Seka A, de Knijf S, Verstaete W. A novel approach to calcium removal from calcium-rich industrial wastewater. Water Res. 2003;37:699-704.

19. Sarayu K, Iyer NR, Murthy AR. Exploration on the biotechnological aspect of the ureolytic bacteria for the production of the cementitious materials: a review. Appl Biochem Biotechnol. 2014; 172:2308-23.

20. Dhami NK, Reddy MS, Mukherjee A. Application of calcifying bacteria for remediation of stones and cultural heritage. Front Microbiol. 2014;5:304.

21. Krajewska B. Ureases. II. Properties and their customizing by enzyme immobilizations: a review. J Mol Catal B Enzym. 2009;59:22-40.

22. Upadhyay LSB. Urease inhibitors: a review. Indian J Biotechnol. 2012;11:381-8.

23. Kosikowska P, Berlicki $Ł$. Urease inhibitors as potential drugs for gastric and urinary tract infections: a patent review. Expert Opin Ther Pat. 2011;21:945-57.

24. Amtul Z, Rahman AU, Siddiqui RA, Choudhary MI. Chemistry and mechanism of urease inhibition. Curr Med Chem. 2002;9: $1323-48$.

25. McCarty GW, Bremner JM, Lee SJ. Inhibition of plant and microbial ureases by phosphoroamides. Plant Soil. 1990;127: 269-83.

26. Todd MJ, Hausinger RP. Competitive inhibitors of Klebsiella aerogenes urease. Mechanisms of interaction with nickel active site. J Biol Chem. 1989;264:15835-42.

27. Dixon NE, Blakeley RL, Zerner B. Jack bean urease (EC 3.5.1.5). III. The involvement of active-site nickel ion in inhibition by $\beta$ mercaptoethanol, phosphoroamidate and fluoride. Can J Biochem. 1980;58:481-8.

28. Todd MJ, Gomez J. Enzyme kinetics determined using calorimetry: a general assay for enzyme activity? Anal Biochem. 2001;296:179-87. 
29. Benini S, Rypniewski WR, Wilson KS, Ciurli S, Mangani S. The complex of Bacillus pasteurii with $\beta$-mercaptoethanol from X-ray data at $1.65 \AA$ resolution. J Biol Inorg Chem. 1998;3:268-73.

30. Juszkiewicz A, Kot M, Zaborska W. Calorimetric study of inhibition of urease by 2-mercaptoethanol: procedures based upon integrated rate equations. Thermochim Acta. 1998;320:45-52.

31. Dixon NE, Hinds JA, Fihelly AK, Gazzola C, Winzor DJ, Blakeley RL, Zerner B. Jack bean urease (EC 3.5.1.5). IV. The molecular size and the mechanism of inhibition by hydroxamic acids. Spectroscopic titration of enzymes with reversible inhibitors. Can J Biochem. 1980;58:1323-34.

32. Krajewska B, Zaborska W, Leszko M. Inhibition of chitosanimmobilized urease by slow binding inhibitors: $\mathrm{Ni}^{2+}, \mathrm{F}^{-}$and acetohydroxamic acid. J Mol Catal B Enzym. 2001;14:101-9.

33. Benini S, Rypniewski WR, Wilson KS, Miletti S, Ciurli S, Mangani S. The complex of Bacillus pasteurii with acetohydroxamate anion from X-ray data at $1.55 \AA$ resolution. J Biol Inorg Chem. 2000;5:110-8.

34. Vassiliou S, Grabowiecka A, Kosikowska P, Yiotakis A, Kafarski P, Berlicki Ł. Design, synthesis, and evaluation of novel organophosphorus inhibitors of bacterial ureases. J Med Chem. 2008;51:5736-44.

35. Vassiliou S, Kosikowska P, Grabowiecka A, Yiotakis A, Kafarski P, Berlicki Ł. Computer-aided optimization of phosphinic inhibitors of bacterial ureases. J Med Chem. 2010;53:5597-606.

36. Berlicki Ł, Bochno M, Grabowiecka A, Białas A, Kosikowska P, Kafarski P. N-substituted aminomethanephosphonic and aminomethane- $P$-methylphosphinic acids as inhibitors of ureases. Amino Acids. 2012;42:1937-45.

37. Breitenbach JM, Hausinger RP. Proteus mirabilis urease. Partial purification and inhibition by boric acid and boronic acids. Biochem J. 1988;250:917-20.

38. Todd MJ, Hausinger RP. Reactivity of the essential thiol of Klebsiella aerogenes urease. Effect of $\mathrm{pH}$ and ligands on thiol modification. J Biol Chem. 1991;266:10260-7.

39. Krajewska B, Zaborska W, Leszko M, Brzózka Z. Inhibition of jack bean urease by a mixture of boric acid and phosphate buffer pH 6.96. Pol J Chem. 1999;73:359-66.

40. Benini S, Rypniewski WR, Wilson KS, Mangani S, Ciurli S. Molecular details of urease inhibition by boric acid: insights into the catalytic mechanism. J Am Chem Soc. 2004;126:3714-5.

41. Krajewska B, Ciurli S. Jack bean (Canavalia ensiformis) urease. Probing acid-base groups of the active site by $\mathrm{pH}$-variation. Plant Physiol Biochem. 2005;43:651-8.

42. Reddy KRC, Kayastha AM. Boric acid and boronic acids inhibition of pigeonpea urease. J Enzyme Inhib Med Chem. 2006;21:467-70.

43. Kumar S, Kayastha AM. Inhibition studies of soybean (Glycine max) urease with heavy metals, sodium salts of mineral acids, boric acid, and boronic acids. J Enzyme Inhib Med Chem. 2010;25:646-52.

44. Krajewska B. Urease immobilized on chitosan membrane. Inactivation by heavy metal ions. J Chem Tech Biotechnol. 1991;52:157-62.

45. Zaborska W, Krajewska B, Olech Z. Heavy metal ions inhibition of jack bean urease: potential for rapid contaminant probing. J Enzyme Inhib Med Chem. 2004;19:65-9.

46. Krajewska B. Mono- $(\mathrm{Ag}, \mathrm{Hg})$ and di- $(\mathrm{Cu}, \mathrm{Hg})$ valent metal ions effects on the activity of jack bean urease. Probing the modes of metal binding to the enzyme. J Enzyme Inhib Med Chem. 2008;23:535-42.

47. Shi D-H, You Z-L, Xu C, Zhang Q, Zhu H-L. Synthesis, crystal structure and urease inhibitory activities of Schiff base metal complexes. Inorg Chem Commun. 2007;10:404-6.
48. Li Y-G, Shi D-H, Zhu H-L, Yan H, Ng SW. Transition metal complexes $(\mathrm{M}=\mathrm{Cu}, \mathrm{Ni}$ and $\mathrm{Mn})$ of Schiff-base ligands: syntheses, crystal structure, and inhibitory bioactivities against urease and xanthine oxidase. Inorg Chim Acta. 2007;360:2881-9.

49. Zhang L, Mulrooney SB, Leung AFK, Zeng Y, Ko BBC, Hausinger RP, Sun H. Inhibition of urease by bismuth(III): implications for the mechanism of action of bismuth drugs. Biometals. 2006;19:503-11.

50. Zaborska W, Krajewska B, Kot M, Karcz W. Quinone-induced inhibition of urease. Elucidation of its mechanisms by probing thiol groups of the enzyme. Bioorg Chem. 2007;35:233-42.

51. Krajewska B, Zaborska W. Double mode of inhibition-inducing interactions of 1,4-naphthoquinone with urease. Arylation vs oxidation of enzyme thiols. Bioorg Med Chem. 2007;15:4144-51.

52. Zaborska W, Kot M, Superata K. Inhibition of jack bean urease by 1,4-benzoquinone and 2,5-dimethyl-1,4-benzoquinone. Evaluation of the inhibition mechanism. J Enzyme Inhib Med Chem. 2002; $17: 247-53$

53. Krajewska B, Zaborska W. The effect of phosphate buffer in the range of $\mathrm{pH} 5.80-8.07$ on jack bean urease activity. J Mol Catal B Enzym. 1999;6:75-81.

54. Benini S, Rypniewski WR, Wilson KS, Ciurli S, Mangani S. Structure-based rationalization of urease inhibition by phosphate: novel insights into the enzyme mechanism. J Biol Inorg Chem. 2007;6:778-90.

55. Todd MJ, Hausinger RP. Fluoride inhibition of Klebsiella aerogenes urease: mechanistic implications of a pseudo-uncompetitive, slow-binding inhibitor. Biochemistry. 2000;39:5389-96.

56. Benini S, Cianci M, Mazzei L, Ciurli S. Fluoride inhibition of Sporosarcina pasteurii urease: structure and thermodynamics. J Biol Inorg Chem. 2014;19:1243-61.

57. Krajewska B. Hydrogen peroxide-induced inactivation of urease. Mechanism, kinetics and inhibitory potency. J Mol Catal B Enzym. 2011;68:262-9.

58. Krajewska B, Brindell M. Urease activity and L-ascorbic acid. J Enzyme Inhib Med Chem. 2011;26:309-18.

59. Krajewska B, Zaborska W, Leszko M. Inhibition of chitosanimmobilized urease by boric acid as determined by integration methods. J Mol Catal B Enzym. 1997;3:231-8.

60. Segel IH. Enzyme kinetics. New Jersey: Wiley; 1975.

61. Font M, Domínguez M-J, Sanmartín C, Palop JA, San-Francisco S, Urrutia O, Houdusse F, García-Mina JM. Structural characteristics of phosphoramide derivatives as urease inhibitors. Requirements for activity. J Agric Food Chem. 2008;56:8451-60.

62. Weatherburn MW. Phenol-hypochlorite reaction for determination of ammonia. Anal Chem. 1967;39:971-4.

63. Ngo TT, Phan APH, Yam CF, Lenhoff HM. Interference in determination of ammonia with the hypochlorite-alkaline phenol method of Berthelot. Anal Chem. 1982;54:46-9.

64. Krajewska B, van Eldik R, Brindell M. Temperature- and pressure-dependent stopped-flow kinetic studies of jack-bean urease. Implications for the catalytic mechanism. J Biol Inorg Chem. 2012;17:1123-34.

65. Krajewska B, Zaborska W. Jack bean urease. The effect of activesite binding inhibitors on the reactivity of enzyme thiol groups. Bioorg Chem. 2007;35:355-65.

66. Dixon NE, Riddles PW, Gazzola C, Blakeley RL, Zerner B. Jack bean urease (EC 3.5.1.5). V. On the mechanism of action of urease on urea, formamide, acetamide, $N$-methylurea, and related compounds. Can J Biochem. 1980;58:1335-44.

67. Lopreore C, Byers LD. The urease-catalyzed hydrolysis of thiourea and thioacetamide. Arch Biochem Biophys. 1998;349:299-303. 
68. Behbehani GR, Saboury AA, Poorakbar E, Barzegar L. Application of the extended solvation model for thermodynamic study of copper ion binding to Jack bean urease. J Therm Anal Calorim. 2010;102:1141-6.

69. Behbehani GR, Saboury AA, Taherkhani A, Barzegar L, Mollaagazade A. A thermodynamic study on the binding of mercury and silver ions to urease. J Therm Anal Calorim. 2011;105:1081-6.
70. Behbehani GR, Saboury AA, Sabbaghy F. A calorimetric study on the interaction of zinc and cadmium ions with jack bean urease. Chin J Chem. 2011;29:446-50. 